\title{
ALFRED DE VIGNY, Stello
}

\section{Lise Sabourin}

\section{(2) OpenEdition \\ Journals}

Édition électronique

URL : https://journals.openedition.org/studifrancesi/43994

DOI : 10.4000/studifrancesi.43994

ISSN : 2421-5856

\section{Éditeur}

Rosenberg \& Sellier

\section{Édition imprimée}

Date de publication : 1 juin 2021

Pagination : 225

ISSN : 0039-2944

\section{Référence électronique}

Lise Sabourin, « ALFRED de VIGNy, Stello », Studi Francesi [En ligne], 193 (LXV | I) | 2021, mis en ligne le 01 juillet 2021, consulté le 14 octobre 2022. URL : http://journals.openedition.org/studifrancesi/43994 ; DOI : https://doi.org/10.4000/studifrancesi.43994

Ce document a été généré automatiquement le 14 octobre 2022.

\section{(c) (1)}

Creative Commons - Attribution - Pas d'Utilisation Commerciale - Pas de Modification 4.0 International - CC BY-NC-ND 4.0

https://creativecommons.org/licenses/by-nc-nd/4.0/ 


\title{
ALFRED DE VIGNY, Stello
}

\author{
Lise Sabourin
}

\section{RÉFÉRENCE}

ALFRED DE VIGNY, Stello, éd. S. Vanden Abeele-Marchal, Paris, Classiques Garnier, 2019, $450 \mathrm{pp}$.

1 Stello est assurément le roman le plus représentatif de la pensée de Vigny, partagé entre l'idéalisme déçu de son héros et les préceptes de sagesse désabusée du Docteur Noir. L'importance de son énonciation, «labile» et «multicolore» grâce au dynamisme du récit-cadre et à la diversité des nouvelles intégrées, fut quasi immédiatement reconnue, grâce aux articles de Planche, Sainte-Beuve et Busoni qui surent en déceler l'originalité, même s'ils eurent quelque mal à le détacher de modèles sternien ou hofmannien, voire diderotien. En fait, c'est du côté des amis poètes de Vigny, Antoni Deschamps et Auguste Barbier, qu'on peut retrouver ce goût d'une satire cathartique et heuristique qui fonde la relation des deux protagonistes de cette «Consultation».

2 L'annotation, abondante, et les leçons du manuscrit, microfilmé par Irving Massey et déposé à Philadelphie, avant la vente de la collection Barthou qui l'a rendu pour le moment inaccessible (en collection privée), font tout l'intérêt de cette nouvelle édition par Sophie Vanden Abeele-Marchal. Son introduction, intitulée «Stello ou les "ciels étoilés“ du poète en 1832» (pp.7-65), étudie l'atmosphère allégorique et réaliste à la fois de ce roman analytique et critique de la crise vécue sous la monarchie de Juillet. La temporalité nocturne retranscrit la réflexion vignyenne sur l'état de la méditation individuelle face à une société en profonde mutation, ce «temps de dégoût et de pâleur» après l'effervescence des idées lamenaisiennes et saint-simoniennes. Crise politique et philosophique, mais aussi philologique et rhétorique dont rend compte la forme novatrice adoptée - difficile, Vigny en était conscient à voir ses corrections sur chaque édition de son roman - mais fondamentale pour refléter la conscience moderne qui se met alors en place. À travers le conflit de figures sous divers régimes (Louis XV face à Gilbert, Beckford à Chatterton, Robespierre et Saint-Just à André Chénier) Vigny, 
conduit à une «neutralité armée» entre un socialisme quasi évangélique et sa nostalgie de la royauté féodale, transpose l'éternel débat entre le législateur social et le poète, guide inspiré mais aussi instrument de subversion: c'était déjà «l'embarras» de Platon devant Homère, incarnation synthétique de la destinée poétique. 